\title{
O culto católico e a representação do corpo masculino na literatura anticlerical brasileira (século XIX)*
}

\section{The Catholic worship and the representation of the male body in Brazilian anticlerical literature (19th century)}

Cristian José OliveiRa SANTOS**

Fundação Casa de Rui Barbosa Rio de Janeiro $(R J)$

Brasil

RESUMO Analisa-se a possível relação entre práticas religiosas e o corpo masculino doentio na literatura anticlerical brasileira do século XIX. Recorreuse, para isso, a análise do personagem Bernardo, protagonista de Morbus: romance patológico, de 1898, do pernambucano Faria Neves Sobrinho, observando o papel dos ritos celebrativos - missa e peregrinação - no seu quadro enfermiço. Conclui-se que o texto em questão é configurado dentro da

* Artigo recebido em: 17/07/2013. Aprovado em: 07/07/2014.

** Doutor em Literatura e Práticas Sociais pela Universidade de Brasília e pós-doutorando em História pela Fundação Casa de Rui Barbosa. Contato: crijol@gmail.com. 
lógica modernizante cientificista e anticlerical oitocentista ao estabelecer vínculos inequívocos entre a histeria masculina e a prática religiosa perversora.

Palavras-chave anticlericalismo, literatura brasileira, Igreja Católica, liturgia, peregrinação

ABSTRACT It analyzes the possible relationship between religious practice and the unhealthy male body in Brazilian anticlerical literature of the nineteenth century. To do that, it examines the character Bernardo, protagonist of Morbus: pathological romance, 1898, from the Pernambuco Faria Neves Sobrinho, noting the role of celebratory rites - mass and pilgrimage - in his sickly frame. We conclude that the text in question is set within the nineteenthcentury scientistic and anti-clerical modernizer logic to establish clear links between male hysteria and perversive religious practice.

Keywords anticlericalism, brazilian literature, Catholic Church, liturgy, pilgrimage

\section{Introdução}

Em 1898, o pernambucano Faria Neves Sobrinho publica Morbus: romance patológico, protagonizado por um jovem beato que no curso da trama sucumbirá ao império das leis da hereditariedade e do meio. O subtítulo do livro remete a uma forte tendência de se transferir para o domínio literário algumas teses apaixonadamente discutidas pela Medicina dos oitocentos. De fato, a obra em questão se sustentará na ideia de que o homem é, fundamentalmente, realidade biológica previamente estabelecida e que vai se configurando a partir da incidência de uma multiplicidade de variáveis.

Amparada na literatura clínica em voga, Morbus discorrerá a respeito do itinerário de vida de Bernardo, jovem brasileiro que herda do pai português radicado em Recife, Sebastião Nogueira, uma predisposição orgânica para a neurose. A mãe, Dona Mência - comumente chamada de D. Mência (poderíamos ler "demência") -, manifesta acentuada fraqueza orgânica, sequela da educação conventual. Por inculcar no filho uma religiosidade doentia, será acusada de contribuir com o fim dramático de Bernardo.

Essa concepção de sujeito sequelado se fundamenta na tese de que o corpo é entidade catalisadora que se configura, gradualmente, a partir da incidência de forças externas que passam a dialogar com elementos orgânicos pré-dispositivos a enfermidade. Morbus não apresenta, simplesmente, o processo de constituição orgânica de um personagem em "cujas veias girava o sangue de um neuropata"1 e que encerrava dentro de si, como uma força

1 NEVES SOBRINHO, Faria. Morbus: romance patológico. 2 ed. Recife: Ed. do Organizador, 2005, p.216. 
criada pela própria doença, a "alma sonhadora de neurótico". ${ }^{2}$ De fato, no curso do romance, Bernardo se metamorfoseará pelo contato com organismos tresloucados por missas teatralizadas e romarias encenadas por sujeitos imorais.

Protagonizada por um neurótico, o texto apresenta o corpo masculino como produto final de um complexo conjunto de infortúnios, tanto no plano biológico quanto no social. Sua infelicidade, esterilidade e reprobabilidade social evidenciam a plausibilidade da tese. É em razão disso que Morbus pode ser classificado como um "estudo das taras"; "taras [que] perseguem duas gerações; o filho de um louco se revela um abucólico". ${ }^{4}$ Nesse contexto, a obra se inclui entre os textos naturalistas de temática ortodoxa, presa aos aspectos enfermiços dos indivíduos. ${ }^{5}$

De fato, os primeiros capítulos do romance enfatizam o triunfo da physis sobre a metafísica, sublinhando o predomínio do corpo em relação a qualquer outra possível realidade tangencial, seja de natureza anímica ou social, sujeitando, portanto, todos os movimentos humanos e papéis sociais ao determinismo estigmatizador da hereditariedade e ao caráter cíclico da morte e da vida. Trata-se de uma tendência dos escritores brasileiros de então de supervalorizar as impulsões fisiológicas na constituição da narrativa em comparação aos escritores do Velho Mundo: "Os naturalistas brasileiros se revelarão (...) infinitamente mais obcecados pelos problemas da carne que seus confrades europeus". ${ }^{6}$

Entretanto, Morbus não é um tratado médico, restrito a arrolar sintomas e terapias. De fato, é travado um embate laboratorial contra forças antimodernistas, desnudando um corpo arcaico e sorumbático, configurado, deterministicamente, por forças externas ligadas à religião. É evidente que as críticas dirigidas à Igreja Católica estejam intimamente associadas ao período histórico em que o romance foi produzido. Apenas dois anos antes da edição de Morbus, aprovou-se o Decreto 119-A, de 7 de janeiro de 1890, precedido por discussões acaloradas nos espaços intelectuais e políticos, que punha termo ao regime do padroado.

O discurso anticlerical se desenvolve na trama a partir da caricaturização do protagonista e, especificamente, de uma descrição satírica do ambiente e de personagens que povoam a trama e que incidirão, agressivamente, na formação psíquica de Bernardo, desde sua meninice. Logo, corpo e religiosidade são realidades indissociáveis em Morbus. As "páginas brilhantes",

\footnotetext{
NEVES SOBRINHO, Faria. Morbus, p.107.

SODRÉ, Nelson Werneck. História da literatura brasileira. 10 ed. Rio de Janeiro: Graphia, 2002, p.436.

PEREIRA, Lúcia Miguel. Prosa de ficção: de 1870 a 1920. Rio de Janeiro: J. Olympio, 1950, p.136.

Poderíamos citar outras, como A Fome (1890), de Rodolfo Teófilo (1853-1932); A Luta (1911), de Carmem Dolores (1852-1910), publicada inicialmente em folhetins do Jornal do Commercio; Alma em Delírio (1909), de Canto e Melo (1866-1934); A Normalista (1893), de Adolfo Caminha (1867-1897); e O Homem (1887), de Aluísio Azevedo (1857-1913), também objeto deste estudo.

6 PICCHIO, Luciana Stegagno. Literatura brasileira: das origens a 1945. São Paulo: Martins Fontes, 1988, p.41.
} 
assim denominadas por Aluísio Azevedo, ${ }^{7}$ se justificam pela maestria de Faria Neves Sobrinho em entrelaçar elementos orgânicos e culturais, particularmente religioso, na compleição do jovem neurótico. O corpo adoecerá pela inserção em um universo poderosamente maléfico.

É nesse sentido que o livro está plenamente comprometido com um projeto cientificista que encara o clericalismo como obscurantista e prejudicial, lançando um pretenso olhar imparcial do seu reuintado e perigoso capital simbólico no processo de aniquilamento do corpo devoto, já vulnerabilizado pela doença herdada do pai. Ao invés de se restringir a entabular sintomas, relaciona-os a elementos "de fora", em particular a prática religiosa, que sequelará o corpo com vertigens, pesadelos, crises morais, alucinações místicas, visões e, finalmente, a morte.

Não se pode compreender Morbus fora da perspectiva do embate firmado entre tradição e Modernidade. O desnudamento do jovem sorumbático pela prática devocional serve de prova inconteste do malefício da religião. Portanto, se a obra insiste, num primeiro momento, em destacar a natureza hereditária da degenerescência de Bernardo, o religioso ocupará a maior parte da trama, seja de forma explícita ou diluída. No presente artigo nos restringiremos em analisar o papel da missa e da peregrinação na configuração do protagonista, buscando estabelecer como a ideologia da Modernidade se deflagra a partir da vinculação da enfermidade com a prática religiosa perversora.

\section{A Liturgia como argumento anticlerical}

Os ritos religiosos tem grande relevância coletiva, já que funcionam como instrumentos que garantem estabilidade ao grupo. De fato, uma de suas principais funções é reduzir, drasticamente, níveis de contradição inerentes a qualquer sociedade. Essa redução da precariedade na malha social se dá por meio da legitimação de uma ordem estabelecida a partir da outorga de um "status cósmico". Ao firmar uma relação entre o nomos e o divino, o mundo, inicialmente precário, se converte em realidade inequivocamente plausível.

O reconhecimento da força de tal vínculo faz com que o discurso antirreligioso parta desse universo simbólico, apresentando-o como um complexo conjunto de estratégias de controle equivocadas e censuráveis. Já nos primeiros séculos, os cristãos foram acusados de sacrificar crianças e beber do seu sangue em ritos secretos, conforme referenciado por Minúcio Félix, em sua obra Octavius (ca. 197), e Tertuliano em Aos pagãos. Em Morbus, a imoralidade dos ritos será duplamente exposta. Primeiramente,

7 Apud CHACON, Vamireh. Faria Neves Sobrinho, ou, a consciência de província. Recife: FUNDARPE, 1986, p.66. 
a Igreja será acusada de fomentar a superstição entre seus fieis e, seguidamente, condenada por adotar uma liturgia pomposa. Faria Neves Sobrinho recorrerá, para isso, a uma narrativa direta e agressiva, limpa de diálogos, buscando, desse modo, conferir objetividade e caráter de totalidade ao fenômeno ritualístico observado.

Desse modo, converte-se numa estratégia estilisticamente poderosa ao incidir no aspecto central da religião. De fato, ainda que toda religião seja constituída por um conjunto entremeado de ritos e crenças, aqueles tem primazia. ${ }^{8}$ Em Morbus, a eficácia devastadora do rito enquanto linguagem se manifesta por meio de uma meticulosa descrição das cerimônias, em particular do seu impacto nos fieis. Ao caracterizar o religioso como "fenômeno mágico", supersticioso, a serviço dos homens, enfatiza-se o rito que, ao invés de se revelar como culto à divindade, se apresenta, incontestavelmente, como "coação sobre o deus". ${ }^{9}$ Ao invés de, simplesmente, negar a relevância do religioso, acusa-se de impuro o cristianismo apregoado pela Igreja.

A partir da comprovação da degenerescência do culto, são problematizadas a inevitabilidade e durabilidade de todo o edifício religioso. Nesse contexto, Faria Neves Sobrinho compartilha com Eça de Queirós a percepção da Igreja como "pervertedora dos ideais primitivos do cristianismo, pela sua aliança com os poderosos e os ricos, pelo seu apoio a uma ordem social eminentemente anti-cristã, pelo seu comprazimento com superstições grosseiras e liturgias materializantes". ${ }^{10}$ Desse ponto, Faria Neves se revelará mais bélico; seguindo a linha cientificista de então, arrolará sujeitos desajustados e, não raramente, maléficos.

Em suma, a sátira anticlerical em Morbus se ocupará em comprovar o grau de anomia da ordem religiosa estabelecida a partir do esquadrinhamento de eventos sociais. Recorre-se aos ritos religiosos por serem "maneiras de agir que só surgem no interior de grupos coordenados e se destinam a suscitar, manter ou refazer alguns estados mentais desses grupos". ${ }^{11} \mathrm{~A}$ pretensão não é, simplesmente, compreender o rito, mas avaliar o seu grau de desvio a partir da análise dos seus efeitos entre as pessoas. De fato, "as representações religiosas são representações coletivas que exprimem realidades coletivas". ${ }^{12} \mathrm{O}$ tom anticlerical se agravará ao comprovar, exatamente, a lacuna entre realidade e idealidade. Em suma, além de desnudar o ambiente enfermiço de uma religiosidade desvirtuada, manifesta nos

8 SMITH, William Robertson. The religion of the semites. New York: Meridian, 1956.

9 WEBER, Max. Sociologia da religião: tipos de relações comunitárias religiosas. In: Economia e sociedade: fundamentos da sociologia compreensiva. 3 ed. v.1, Brasília: Editora Universidade de Brasília, 1994, p.292.

10 MATOS, Alfredo Campos. Anticlericalismo. In: MATOS, Alfredo Campos (org.). Dicionário de Eça de Queiroz. Lisboa: Caminho, 1988, p.78.

11 DURKHEIM, Émile. As formas elementares da vida religiosa. São Paulo: Martins Fontes, 1996, p.XVI, tradução nossa.

12 DURKHEIM, Émile. As formas elementares da vida religiosa, p.XVI. 
olhares, vestuários, gesticulações e sentimentos dos devotos, Morbus comprovará o terrível impacto que tais imagens forjadas por homens hipócritas e interesseiros terão no organismo do jovem beato.

Como já dito, dois atos celebrativos são descritos, pormenorizadamente, no romance: uma romaria de cunho penitencial, sob o sol escaldante de Recife, e uma missa solene e abafadiça. Os dois eventos se dialogam no próprio modo com que os ritos vão sendo descritos. Esta complementaridade estética se respalda no próprio conceito de ritual. Os gregos antigos já reconheciam a dupla faceta do rito: ao mesmo tempo em que abarca as coisas que precisam ser feitas (dromena), contempla as coisas que precisam ser ditas (legoumena). ${ }^{13}$ Observaremos, adiante, que Morbus contempla essas duas modalidades de rememoração do sagrado, cenas em que se deflagrarão as críticas mais incisivas à religião católica.

\section{A peregrinação: crença ou poder?}

A peregrinação é uma prática difundida entre diversas religiões. De modo genérico, podemos afirmar que se trata de um ato de reconhecimento da onipotência divina. ${ }^{14} \mathrm{Em}$ Morbus, a romaria será evocada como instrumento estético poderoso no processo de crítica à lgreja. O autor recorrerá a dois pontos na construção de sua argumentação: primeiro, o rito deflagra papeis sociais e, segundo, é desprovido de significados, apesar da formalidade. ${ }^{15}$

Relata-se em detalhes o percurso dos romeiros até a ermida olindense. Por meio do beato Simplício, se estabelece a acepção da romaria enquanto projeto humano intervencionista, penitencial e salvífico. Nesse sentido, a romaria se inclui, efetivamente, entre as coisas que precisam ser feitas (dromena): "a necessidade indiscutível dos sacrifícios e das penitências, para que, após a morte, Ihes fosse concedida a ventura suprema da bemaventurança". ${ }^{16} \mathrm{~A}$ crença na vida post mortem e na possibilidade de se intervir na decisão divina por meio de cerimônias específicas está indiscutivelmente associada a um conjunto de crenças. Em outras palavras, o ritualismo em Morbus se incluiria entre as manifestações simbólicas da fé de um povo, estabelecidas por meio de um conjunto de verdades. Entretanto, não é a fé do romeiro que se enaltece no texto literário, mas duas funções autônomas e

13 GRASSI, Ernesto. Language as the presupposition of religion: a problem of rhetoric as philosophy? In: Rhetoric as philosophy: the humanist tradition. Carbondale: Southern Illinois University Press, 2001, p.102-114.

14 BOZZONE, Antonio Maria. Pellegrinaggi. In: MERCATI, Ângelo; PELZER, Augusto. Dizionario ecclesiastico. Torino: Unione, 1953-1958, p.135-136.

15 Interessante observar que Machado de Assis (Carta ao Senhor Bispo do Rio de Janeiro. In: Obra completa. Rio de Janeiro: Aguilar, 1973. p.975-976), aos 22 anos, publica em 18 de abril de 1862, no Jornal do Povo, a "Carta ao Sr. Bispo do Rio de Janeiro", na qual, ao lamentar o estado de prostituição litúrgica em que se encontrava o catolicismo, cita o caso das procissões que "derivando de usanças pagãs, não podiam continuar a ser sancionadas por uma religião que veio destruir os cultos da gentilidade".

16 NEVES SOBRINHO, Faria. Morbus, p.216. 
interdependentes do rito: reforçadora da solidariedade social e mantenedora de uma ordem social já estabelecida, em que clero e laicato são representados de forma radicalmente distinta e, em certos casos, oposicionista.

Quanto a manutenção da estrutura, a figura do homem religioso na trama, tanto clérigo quanto leigo, se dá a partir da indicação da presença de um ou mais predicados não esperados. A hipocrisia, nesse sentido, deve ser concebida como nódoa que introduz o sujeito em um estado anômalo. Ainda que compartilhem esse "desvio", observaremos que a construção simbólica de cada um dos grupos - laicato e clero - é muito distinta.

O laicato é a personagem coletiva da trama. Mesmo sofrendo uma rigorosa taxonomização - reduzido a três grupos de romeiros -, esses tipos são homogeneizados a partir do compartilhamento de duas marcas: são destituídos de um nome e de vontade própria. O laicato é caracterizado, portanto, por sua condição de falta, de ausência, sendo os seus membros convertidos em sujeitos massificados, "um conjunto curiosíssimo de carolismo e hipocrisia". ${ }^{17}$ Frequentemente será evocado como rebanho, caracterizados por movimentos marcados por uma docilidade métrica, semelhante a uma máquina perfeitamente ajustada. Essa mecânica enquanto entidade coletiva passiva e alienada se manifestará tanto no comportamento quanto no campo fisiológico:

Uns sessenta, quase todos de preto, circunspectos e calvos, enchiam o pátio, divididos em pequenos grupos de três a quatro, em conversas comedidas, como se soprassem ladainhas uns aos ouvidos dos outros. Um sussurro abafado, misterioso, jesuítico (...).

Outros, escorreitos, compridos como varas, duros, tesos, empertigavam-se majestosamente nas pernas altas e despediam dos olhos pequeninos olhares quentes e superiores para tudo (...), cônscios de que representavam papel salientíssimo, digno de admirações e de aplausos. Estes palravam, tinham gestos desdenhosos, levantamento de ombros, posturas estudadas de arrogância. Ainda outros, minguados, raquíticos, inquietos, de olhinhos piscos e redondos, iam e vinham, de um grupo a outro, estonteados, impacientes

Havia-os também brejeiros e maliciosos, narradores de pilhérias equívocas, arrepanhando os lábios em risinhos ocultos e disfarçados.

De resto, formavam todos uma amálgama de temperamentos heterogêneos, um conjunto curiosíssimo de carolismo e hipocrisia. Exceções raríssimas, surgiam aqui e além, dentre todas, cabeças evangélicas de verdadeiros crentes, convictos de inúmeras iniqüidades praticadas por pensamentos, palavras e obras, e capazes de, em expiação de pecados, se tal Ihes fora ordenado em bem da salvação das almas, arrastarem-se por estradas longas e ásperas, em peregrinações infindáveis, contanto que purificadoras. ${ }^{18}$

Reconhece-se, portanto, o papel do coletivo no estabelecimento contínuo de crenças, o que nos leva a concluir que a eficácia da religião como

17 NEVES SOBRINHO, Faria. Morbus, p.232.

18 NEVES SOBRINHO, Faria. Morbus, p.232. 
instituição definidora da realidade é ressaltada. De fato, "quase todas as grandes instituições sociais nasceram da religião". ${ }^{19}$ Sabendo que "a religião engendrou tudo o que há de essencial na sociedade, (...) a ideia da sociedade é a alma da religião", ${ }^{20}$ busca-se esvaziar a ordem estabelecida, acusando-a de anômala. Isto se fará pela descrição dos corpos e das psiques desajustadas, das falas espontâneas tresloucadas dos personagens e do pretenso olhar "objetivo" do narrador, ou seja, pelo descortinamento do estado deteriorado do indivíduo chafurdado nessa estrutura pautada pelo culto ao anacronismo. Registra-se, dentro da linguagem literária, o que Goffman ${ }^{21}$ chamou de identidades sociais deterioradas, ou seja, o resultado e, ao mesmo tempo, o processo cíclico de desumanização do indivíduo.

É importante observarmos que a configuração da grei na romaria, desprovida de voz e nome, destoa do personalismo de um "pequeno resto" apresentado na narrativa. A primeira fila é constituída por um grupo seleto de romeiros: Simplício, com sua "cara mefistofélica", 22 o gordo Padre Anacleto e, finalmente, o magérrimo Padre Anastácio. Este último surge, já no início da trama, como assíduo frequentador da casa de Sebastião e Dona Mência; seu corpo decrépido - "Magro, alto, pele pergaminada, ares de tísico, curvo pela asma"; 23 "figura esguia, funambulesca (...), com as suas grandes pernas magras de tísico", ${ }^{24}$ - e imundo - "colete nodoado de manchas sebáceas"; 25 "o colete cheio de nódoas"26 - revela sua posição no mundo. Sob "gritos esganiçados" 27 e com o apoio irrestrito do Vigário e de Simplício, defende cegamente a obediência ao magistério eclesiástico:

Todos os homens deviam contentar-se com obedecer aos preceitos da Igreja e dos Evangelhos, sem discuti-los, nem procurar entendê-los; que isto de pretender-se provar que os sábios conseguem, à força de estudo e de observação, perscrutar os desígnios do Altíssimo e estabelecer leis para os movimentos da lua, dos cometas, das estrelas e de mais um milhão de coisas, não passava de uma refinada tolice, de um requintado orgulho, que mais tarde seria convenientemente recompensado com os trinchantes do Belzebu! Sábio, ninguém o era mais do que ele, Anastácio, que se satisfazia com acreditar na existência de Deus, a eterna sabedoria!28

A tríade de personagens em questão torna manifesto o lado oportunista da práxis religiosa. Padre Anastácio reflete em seus comportamentos um

19 DURKHEIM, Émile. As formas elementares da vida religiosa, p.462.

20 DURKHEIM, Émile. As formas elementares da vida religiosa, p.462.

21 GOFFMAN, Erving. Estigma: notas sobre a manipulação da identidade deteriorada. Rio de Janeiro: Zahar, 1975.

22 NEVES SOBRINHO, Faria. Morbus, p.232.

23 NEVES SOBRINHO, Faria. Morbus, p.37.

24 NEVES SOBRINHO, Faria. Morbus, p.167.

25 NEVES SOBRINHO, Faria. Morbus, p.103.

26 NEVES SOBRINHO, Faria. Morbus, p.167.

27 NEVES SOBRINHO, Faria. Morbus, p.88.

28 NEVES SOBRINHO, Faria. Morbus, p.88. 
misto de autoritarismo e oportunismo, negando, assim, o espírito evangélico e transformando o sacerdócio em carreira vantajosa: "engordado pelas delícias das sonecas e dos rendimentos pingues da Matriz". ${ }^{29}$ Simplício, por sua vez, é tão interesseiro e violento quanto o Vigário; só se distingue deste por ser leigo e por ter como objetivo único em sua vida aproveitar-se de seu cargo como fundador e presidente de uma irmandade para obter fama de benemérito, enchendo, assim, o seu cofre de sândalo com recortes de notícias elogiosas a seu respeito. Anastácio, finalmente, é apresentado como a encarnação da estupidez e da empáfia.

Será incorporado ao grupo, mais à frente, o Dr. Porciúncula, homem culto, redator da Aurora Católica. Mesmo encabeçando a romaria, não se confundirá com os outros tipos descritos. De fato, ele encarnará a figura do católico intelectualizado, de autoridade reconhecida. A bajulação de Simplício corrobora o prestígio do redator.

São diversas as marcas que distinguem Porciúncula do rebanho de penitentes, bem como da "tríade": os óculos, a sobrecasaca corretamente abotoada, a fala pausada, o indicador em riste ao se pronunciar, as citações a Santo Tomás de Aquino. Ele atuará como uma espécie de exegeta, porta voz da Igreja burocratizada. Há uma multiplicidade de comportamentos do personagem, vinculados ou não à cena da romaria, que estabelece este caráter de estranhamento, de não pertença ao grupo dos "católicos ordinários":

Encarrega-se de computar o número de romeiros, não se incluindo entre eles, evidenciando, assim, sua qualidade de cristão de primeira linha, detentor de uma identidade particular na estrutura eclesial: "E, recolocando os óculos, a calcular o número de romeiros". ${ }^{30}$

Reconhece, adotando um tom de autoridade, a validade da romaria, mesmo sem ter sido completada em razão do calor abafadiço; o narrador, por sua vez, põe em xeque o seu discurso: "O redator da Aurora Católica mastigou uma resposta equívoca: 'Em rigor, já havia sido inteiramente cumprida a penitência'”. ${ }^{31}$ Ironicamente, dá-se por escusado no cumprimento da caminhada em razão do calor.

Analisa, com primazia, o "problema" da castidade de Bernardo. Pondera o fato e ajuíza cautela, chegando a levantar a hipótese de o fenômeno ser defeito orgânico ou mero boato, fruto do "instinto maléfico dos acatólicos, que, despeitados pelo fervor religioso de Bernardo, procurassem cobri-lo de ridículo, criando-lhe a fama de donzel!...".32 Sarcasticamente é comparado pelo narrador ao Doutor Angélico: "mão fechada e indicador em riste

29 NEVES SOBRINHO, Faria. Morbus, p.241.

30 NEVES SOBRINHO, Faria. Morbus, p.252.

31 NEVES SOBRINHO, Faria. Morbus, p.275.

32 NEVES SOBRINHO, Faria. Morbus, p.287. 
(...) filosofou sobre o assunto, fitando o espaço com o olhar vago de um iluminado, como se the cochichasse aos ouvidos a pomba mística de S. Tomaz de Aquino". ${ }^{33}$ Após escutar o grupo seleto - o Vigário, o Coadjutor e Simplício -, declara Bernardo possuidor de íntegra castidade, incluindo-o, decisivamente, entre as "almas de pérola, brancas, imaculadas". ${ }^{34}$ A autoridade do Dr. Porciúncula é irrestrita. Mesmo os curas se submetem à sua decisão de sagrar Bernardo santo ainda em vida. Ironicamente, reconhecerá, mais tarde, a impossibilidade de discernir, efetivamente, os herdeiros da vida celeste: "Quantos, quantos do que nos parecem merecedores das galas eternas, são repelidos pela divina justiça, como indignos!...". ${ }^{35}$

Sua fala é totalizante, estabelecendo relações de causalidade entre Deus e o fenômeno sobrenatural, "servindo-se de uma tecnologia rebuscada e erudita" ${ }^{36}$ e elencando as armadilhas discursivas que serão adotadas pelos inimigos da Igreja: "Principalmente, continuou, a virtude sublime e peregrina da castidade! Ah! Para esta os impuros tinham a arma venenosíssima da chacota, do ridículo, da pilhéria grosseira e imunda, cheirando a mofo de roupas de meretrizes". ${ }^{37}$

Observa-se que a função do personagem em questão é preservar a ortodoxia da fé, bem como outorgar um caráter legítimo às manifestações de religiosidade popular, grupo em que a romaria se insere.

O discurso de Simplício na cena da romaria tem uma função símile, mas não idêntica. Ele reitera o aspecto penitencial do rito em questão que, em linhas gerais, evoca a santidade da Igreja, apregoa a transitoriedade da vida e a eternidade da alma, desqualifica a sociedade moderna e diaboliza o corpo dos penitentes. Dentro de uma perspectiva anticlerical, o classificamos de reacionário:

Parabéns à sociedade que representamos! Parabéns a nós mesmos, que, inspirados pelos princípios da religião três vezes santa, conseguimos realizar (...) o mais edificante dos preceitos eternos da igreja - a penitência! Parabéns a nós mesmo que, no meio da corrupção de costumes, que por toda a parte lavra devoradamente como um fogo de incêndio, soubemos sacrificar o repouso de nossos corpos pecaminosos, os confortos voluptuosos do leitos macios, os descansos preguiçosos do nosso lar, ao dever imperiosíssimo, inadiável, da salvação de nossas almas, procurando chegar deste modo ao destino para o qual nos formou a Onipotência divina! Senhores, memento, homo, quia pulvis es, ${ }^{38}$ dizem as sagradas letras. Sim! Todos nós reconhecemos esta suprema verdade e, por isto, dentro em pouco estaremos a caminho de afastada ermi-

33 NEVES SOBRINHO, Faria. Morbus, p.290.

34 NEVES SOBRINHO, Faria. Morbus, p.290.

35 NEVES SOBRINHO, Faria. Morbus, p.313.

36 NEVES SOBRINHO, Faria. Morbus, p.287.

37 NEVES SOBRINHO, Faria. Morbus, p.287.

38 Esta frase - Lembra-te homem que és pó e ao pó tornarás - sintetiza o significado ideal da romaria. 
da, onde, prostrados por terra, imploraremos da Bondade infinita o perdão de nossas iniqüidades. ${ }^{39}$

Ambos, Dr. Porciúncula e Simplício, defendem o valor do rito como mecanismo eficiente de preservação da ordem coletiva. Nesse sentido, os dois personagens visibilizam o estado permanente de combate entre duas ordens sociais, intimamente associadas a forças cosmogônicas em conflito: o bem e o mal. De um lado a Igreja, "três vezes santa", e do outro lado, os corrompidos ou, ainda, os opositores às investidas interesseiras do professor. É nesse sentido que se explica a preocupação exacerbada de garantir que todos os elementos cênicos da "boa catolicidade" - o silêncio absoluto, a circunspecção, os passos lentos e compassados, as cabeças cabisbaixas, certos de que "representavam nesse momento um grupo de arrependidos" 40 - fossem respeitados com o maior rigor, manifestando, assim, a ordem social e, mais ainda, o espírito evangélico do presidente da irmandade. Nesse sentido, o rito em questão se arquiteta como recurso corroborador da ordem social instituída e da veneração da figura de Simplício. Isso se expressa em sua fala cheia de fúria e zelo, ao notar o clima de anarquia geral entre os peregrinos:

Uma romaria tão bem organizada, que partira do adro da matriz com uma
ordem extraordinária, num primor de silêncio e de recolhimento jamais visto,
esfacelar-se assim, sem motivo aceitável, como se fora constituída por imbecis,
por estúpidos que não compreendessem a necessidade de conservar até às
últimas a união do começo, ao menos, houvesse alguma coisa de respeitável
nessas coisas de peregrinagem!
E todo ele estremecia á ideia de que, por leviandade, qualquer indiscreto, de
volta ao Recife, fosse bater língua nos dentes, tagarelar aos quatros cantos da
cidade, contar pelas ruas esse fracionamento da romaria, essa desordem que
decompusera as fileiras dos peregrinos apenas a umas setecentas braças de
distância do ponto de partida. (...) A tão preconizada peregrinagem, destinada
a servir de exemplo de humildade, de ordem, de arrependimento, degenera-
ra, minutos após a saída, num bando de homens dispersos, indisciplinados,
confusos?!... Onde a energia, a força moral do ilustre Sr. Presidente? Onde a
obediência, o respeito às suas determinações, aos seus conselhos?!...

Em síntese, o discurso anticlerical na romaria foca, além da descrição dos corpos e psiques enfermiços dos personagens, outros sinais de flagrante desvio, o que leva o leitor a concluir que tal prática ritualística está desprovida de qualquer espírito genuinamente cristão:

39 NEVES SOBRINHO, Faria. Morbus, p.234.

40 NEVES SOBRINHO, Faria. Morbus, p.235.

41 NEVES SOBRINHO, Faria. Morbus, p.275. 
a) A preocupação afetada de Simplício em se apresentar com trajes novos, destoando dos "balandraus surrados, sobrecasacas de idade duvidosa" ${ }^{\prime 2}$ dos outros peregrinos:

A roupa nova mandada fazer propositadamente para a romaria, (entendera que, na qualidade de presidente da sociedade promotora da peregrinação, era-Ihe dever apresentar-se encadernado em lustrina preta, talhada em sobrecasaca, e pôr à cabeça reluzente e respeitabilíssimo chapéu de seda). ${ }^{43}$

b) A relação de causalidade entre enfermidades físicas e práticas religiosas fanáticas: o estrabismo como seqüela de olhares enviesados aos santos dos altares; ${ }^{44}$

c) A soberba do presidente da irmandade em ser ouvido e venerado pela massa laical:

Fez-se longo silêncio. Simplício, do alto, dardejava, através dos óculos pretos, olhares radiantes sobre o auditório. Um júbilo intenso cantava-Ihe n'alma neste momento; sentia-se elevado, como que pairando acima de nuvens, e, intimamente, diante daqueles homens ávidos de escutá-lo, comparava-se a um monarca diante de quem se prosternassem vassalos. ${ }^{45}$

d) A evidência de que o silêncio imposto aos romeiros era mera estratégia de causar certo impacto teatralizante junto aos de "fora": "Decididamente estava arrependido de ter aconselhado o máximo silêncio aos romeiros!" ${ }^{46}$

e) A religiosidade enfadonha das ladainhas: as típicas manifestações de piedade cristã, como a oração pública, são ilustradas como práticas destituídas de sentido. De fato, se dentro da perspectiva weberiana poderíamos classificar a ladainha como "prática tecnicamente racionalizada da reza", em que praticamente desaparecem as raias entre fórmulas mágicas e a súplica, esta aparece tendo um significado instintivo e irracional, de verdadeira coação a divindade, em que "o rezador apresenta ao deus os serviços prestados, esperando contraprestações correspondentes". ${ }^{47}$

f) A única pretensão da romaria era atender aos reclames de Simplício, fazendo-o ganhar notoriedade:

Talvez as redações do Diario e da Aurora Católica (...) tivessem enviado representantes. E Simplício não pôde conter-se. Voltou o rosto para os lados, para trás, a verificar, de relance, entre os peregrinos a existência de um semblante que tivesse a probabilidade de pertencer a um jornalista. Infrutífera a tentativa.

42 NEVES SOBRINHO, Faria. Morbus, p.275.

43 NEVES SOBRINHO, Faria. Morbus, p.212-213.

44 NEVES SOBRINHO, Faria. Morbus, p.233.

45 NEVES SOBRINHO, Faria. Morbus, p.233.

46 NEVES SOBRINHO, Faria. Morbus, p.236.

47 WEBER, Max. Sociologia da religião, p.292. 
(...). Uma caretazinha de desgosto arrepanhou-lhe o lábio superior, pondo-o, sem grande esforço, em tangência com o nariz adunco. ${ }^{48}$

De todo modo, o arcabouço simbólico alcança um alto grau de plausibilidade junto aos romeiros. É na romaria que Bernardo sofre uma segunda metamorfose. Seus pavores e crises nervosas desaparecem por completo. Inesperadamente, torna-se tranquilo, come pouco, manifesta grande ternura pela mãe, só saindo de casa para ir ao trabalho e à igreja. O percurso religioso entre Recife e Olinda o reintroduz no universo sobrenatural, tão bem incutido pela genitora e por Simplício em sua infância. O que parece em ruínas para o narrador configura-se em uma realidade plausível e harmônica para o nevropata.

Enfatiza-se, sobremodo, a percepção equívoca e desfocada do jovem, incapaz de discernir os fatos, ignorância motivada por "seus olhos míopes de crente". ${ }^{49} \mathrm{O}$ importante é reconhecer o papel do rito enquanto elemento primordial na construção de significados coletivos e individuais. Em outras palavras, a cena da romaria se converte em locus produtor de alternativas ideológicas voltadas para a manutenção do status quo da religião enquanto ordem social vigente. ${ }^{50}$

A peregrinação pode, também, ser compreendida como uma estratégia de sobrevivência por parte dos "anormais", ou seja, dos estigmatizados, especialmente do atormentado Bernardo. Frente a um mundo não receptivo, a partilha da espacialidade, ou seja, a agregação de pessoas funcionaria como instrumento de socialização, fissurando o isolamento a partir da valoração do atributo comum entre eles: a alienação religiosa. Para Bernardo representa uma saída das esferas marginais da "irrealidade" ao nomos socialmente estabelecido, a saber, a religião como práxis coletiva norteadora de sua própria individualidade. Estabelece-se, efetivamente, uma leitura antitética entre corpo e alma. Se o corpo físico após a romaria se manifesta alquebrado com as práticas grotescas da peregrinação, o comportamento sofre mudanças abruptas:

a) Desaparece todo nervosismo frente às maiores adversidades, comportamento patológico herdado do pai:

Comedimento excessivo de gestos e palavras, uma resignação piedosa para todas as contrariedades. Às vezes, raramente, uns gestos da antiga irascibilidade punham-lhe no organismo uns pruridos de revolta, faziam-no falar alto, resmungar, impacientar-se. Mas logo se retraía, humilhado e súplice, a implorar desculpas

48 NEVES SOBRINHO, Faria. Morbus, p.236-237

49 NEVES SOBRINHO, Faria. Morbus, p.271.

50 TURNER, Victor Witter; SWARTZ, Marc J. Introduction. In: TURNER, Victor Witter; SWARTZ, Marc J. (orgs.). Political anthropology. Chicago: Aldin, 1966. 
por mil modos, a acusar-se de mau, com lágrimas indiscretas perlando-lhe as pálpebras. ${ }^{51}$

b) Converte a antiga mesa em que, outrora, se dedicava ao estudo das ciências jurídicas, em uma espécie de altar. Os livros, por sua vez, dão lugar ao crucifixo, figura recorrente na literatura piedosa que evoca a imagem da dor e do fracasso:

Ajoelhado diante de um crucifixo postado sobre sua antiga banca de estudos, curvo e trêmulo, rolava entre os dedos as contas de um rosário, todo ele transfigurado por um esforço íntimo, tão ansioso, tão abatido, como se quisera, à força da sinceridade de seu arrependimento, arrancar da estátua imóvel do crucificado um gesto misericordioso de absolvição. ${ }^{52}$

A imagem do crucificado lá se achava sobre a antiga banca de estudos. ${ }^{53}$

c) Vai se convertendo em um indivíduo supersticioso, temeroso de ser lançado aos infernos se não desse esmola ou não retirasse o chapéu ao passar frente à igreja. Nesse último caso, compensava a irreverência descobrindo a cabeça três ou quatro vezes. Chegou a atribuir o fato de ter sido vítima de um sonho diabólico em razão de estar dormindo "de costas voltadas para o crucificado" 54 , o que o levou a modificar a disposição dos móveis de seu quarto. Até os objetos deveriam estar de face para o Cristo, incluso sapatos e roupas usadas: "à medida que o fora avassalando a monomania religiosa, foram-se-Ihe despertando no espírito superstições inadmissíveis, receios, dúvidas, medos, um conjunto de ideias absurdas e dementes". ${ }^{55}$

d) Submete-se a jejuns rigorosos, apesar de sua "organização debilíssima, incapaz de excessos". ${ }^{56}$

e) No começo, frequentava apenas as missas dominicais e dos dias santos. Depois tornou-se

frequentador infalível da missa das sete, celebrada diariamente pelo Vigário no altar-mor. Ouvia-a então toda, de joelhos, a manusear beatamente um livro de rezas, entre cujas páginas amareladas guardava um sem número de gravuras, de imagens litografadas de santos e santas, toda uma coleção de registros, de estampas devotas, representativas dos martírios de Cristo, das dores de Maria e de outros muitos assuntos de crença. ${ }^{57}$

51 NEVES SOBRINHO, Faria. Morbus, p.276.

52 NEVES SOBRINHO, Faria. Morbus, p.277.

53 NEVES SOBRINHO, Faria. Morbus, p.282-283.

54 NEVES SOBRINHO, Faria. Morbus, p.279.

55 NEVES SOBRINHO, Faria. Morbus, p.278.

56 NEVES SOBRINHO, Faria. Morbus, p.275.

57 NEVES SOBRINHO, Faria. Morbus, p.277. 
f) Permanece ajoelhado na igreja, sempre imóvel - "numa imobilidade de estátua". 58

g) Regula o tempo: confessa-se sempre às sextas-feiras, "uns pecadilhos leves, ligeiríssimos como plumas, incapazes mesmo de o levarem ao purgatório". 59

\section{A missa: crença ou superstição?}

A celebração do culto divino se constitui em uma das cenas mais representadas na literatura anticlerical oitocentista, disputando, possivelmente, o primeiro lugar, apenas, com as cenas de confessionários. Historicamente, o rito eucarístico foi concebido de modos diversos. Tendo sua gênese na páscoa judaica, a celebração em questão é configurada enquanto memorial eficaz na construção de uma identidade coletiva frente a um Deus encarnado e salvador. A missa representada no romance se afasta desta leitura, se aproximando da concepção vigente no século IX, em que a eucaristia "reduziu-se a uma celebração polarizada em torno do sacerdote, do altar, das orações e dos gestos dos celebrantes". ${ }^{60}$ É a partir da ênfase atribuída ao formalismo ritualístico, gerido por especialistas do sagrado e consumido, passivamente, por leigos idiotizados, que a crítica será tecida.

De fato, a acidez anticlerical recai, basicamente, sobre as superstições sobejantes presentes no espaço celebrativo, em especial, a ideia da hóstia profanada e vertendo sangue, mito explorado à exaustão na literatura dos oitocentos. A ostentação cultual é apresentada desde o início do romance como um dos elementos nevrálgicos da potencialização da crendice. O primeiro elemento fanatizante exterior ao locus doméstico e escolar são as alfaias de Padre Anastácio, que seduzem Bernardo à vida religiosa: "via-se trajando finíssimo roquete das mais belas rendas, sobrepelizes barradas de riquíssimos bordados, capas roxas e brancas, debruadas de brocados de ouros e lenteijoladas de estrelinhas". ${ }^{61}$

Sabemos que "a estereotipagem religiosa dos produtos das artes plásticas (...) está condicionada tanto diretamente por ideias mágicas quanto indiretamente pela produção profissional que surge como conseqüência do significado mágico do produto". ${ }^{62}$ O padre, portanto, se reveste da autoridade de mediador do sagrado a partir de um arcabouço simbólico que garante aos destituídos dos poderes supra-sensíveis o acesso ao divino por meio da operação mágica:

58 NEVES SOBRINHO, Faria. Morbus, p.278.

59 NEVES SOBRINHO, Faria. Morbus, p.284.

60 PADOIN, Giacinto. O pão que eu darei: o sacramento da eucaristia. São Paulo: Paulinas, 1999, p.146.

61 NEVES SOBRINHO, Faria. Morbus, p.83.

62 WEBER, Max. Sociologia da religião, p.285 
A invocação não é uma oração, mas uma fórmula mágica: um fundamento inexterminável da religiosidade popular, sobretudo na Índia, porém divulgado universalmente, como mostra o exemplo do sacerdote católico que ainda conserva algo desse poder mágico na transubstanciação da missa. ${ }^{63}$

Com o fausto da missa em desagravo ao Santíssimo Sacramento, reafirma-se o caráter da missa - com seus altares laterais iluminadíssimos, o cibório dourado e o esfarfalhar das opas coloridas dos membros das irmandades - a evento social em que a religião é mera justificativa para oportunizar encontros: "E eram gritinhos, pragas, esconjuros mal contidos, acotovelamentos, perguntas, toda uma confusão evangélica, um charivari beato, um brouhaha que embalde, religiosamente, tentavam sofrear". ${ }^{64}$

A igreja matriz, ambiente propício à quietude e paz, se converte numa espécie de inferno terrenal, desestabilizador, inclusive, das funções orgânicas: "Um calor extraordinário evolava-se de todos os corpos e o ar corrompido por um milhar de hálitos tinha alguma coisa de enervante, de deprimente, um excesso insuportável de carbono, que asfixiava os pulmões. Mesmo causava um certo mal aos nervos". 65

Toca-se no fenômeno da superstição por meio do contexto em que se celebra o rito. Trata-se de uma missa em desagravo a Jesus sacramentado, profanado por ladrões que roubaram o cibório de ouro contendo as partículas consagradas em uma igrejinha europeia. A narrativa é detalhista ao descrever o fim dos sacrílegos:

No dia seguinte, ao ser descoberto o crime assombroso, fora encontrado de borco, sobre os degraus do altar, o cadáver de um dos salteadores, todo contorcido, enroscado quase, com uma expressão diabólica no rosto hediondo e salpicos de sangue pelas vestes. Pesquisada a origem dos salpicos, outras nódoas sangrentas foram notadas sobre a toalha do altar e, dentro do sacrário violado, uma hóstia sangrava copiosamente.

Observa-se a tentativa por parte do narrador em se ater aos fatos ocorridos. Efetivamente, a cena em questão Ihe permitirá focar os olhos sobre o comportamento fanático da turba recifense. Se para Weber a distinção entre magia, religião e culto é passível de ser realizada, mesmo que sem grande profundidade, já que o ritual "contém quase por toda parte grande número de componentes mágicos", ${ }^{66}$ o narrador evoca o rito esvaziado de sistematização racional, resvalando numa idiotia coletiva. A cena da missa evoca a ideia de que o culto católico é centrado no sensível, na prática

63 WEBER, Max. Sociologia da religião, p.292.

64 NEVES SOBRINHO, Faria. Morbus, p.255.

65 NEVES SOBRINHO, Faria. Morbus, p.257.

66 WEBER, Max. Sociologia da religião, p.294. 
profissional dos sacerdotes. Trata-se de uma externalidade fria, vazia, o que Weber ${ }^{67}$ intitulou de "salvação ritual" em que se

dá maior importância ao "conteúdo sentimental" do momento de devoção, que parece garantir a salvação, especialmente quando limita o leigo ao papel de espectador ou a uma participação em forma de manipulações simples ou principalmente receptivas, e isto precisamente quando sublima a espiritualidade ritual no máximo possível a uma devoção sentimental.

\section{Conclusão}

O jovem Bernardo é portador de morbidade, palavra oriunda do latim, morbus, que designa tanto uma patologia física, como uma doença do espírito, ligada às paixões. Sua enfermidade abarca elementos orgânicos e sociais. Desse modo, seu quadro enfermiço vai se configurando a partir do entrelaçamento de marcas corpóreas e anímicas. A enfermidade, portanto, só pode ser devidamente compreendida com o efetivo esquadrinhamento da corporeidade e dos elementos sensíveis que produzem oscilações na alma do jovem. O universo simbólico religioso se inclui entre essas diversas variáveis. De fato, veremos que a prática religiosa se revelará de grande importância na patogênese do protagonista, modelando sua psique e sua corporeidade, sempre em plena harmonia, seja por meio do discurso materno, da orientação espiritual dos clérigos ou do castigo pedagógico e cristão infligido por Simplício. A descrição minuciosa dos tipos, em particular por meio da apresentação dos ritos e seus espaços, conduz o leitor a censurar, irrevogavelmente, o universo religioso pelo malefício feito ao jovem beato.

Com essa pretensão denunciadora, Faria Neves Sobrinho se revela mestre em descrever esse conjunto celebrativo, particularmente os vinculados à romaria à Igreja do Monte e a missa solene, em que a irracionalidade do culto e a estupidez dos fieis revelarão a natureza anacrônica do catolicismo, o que, de certo modo, já prenuncia o fim trágico do jovem Bernardo, vitimado pelo capital simbólico eclesial.

67 WEBER, Max. Sociologia da religião, p.294. 